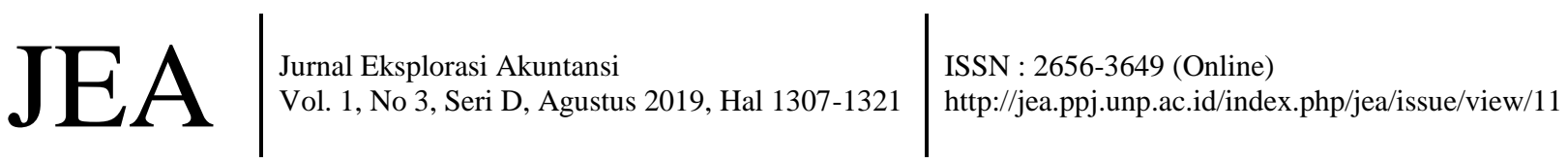

\section{PERILAKU MANAJEMEN LABA BERDASARKAN SIKLUS HIDUP PERUSAHAAN}

(Studi Empiris Pada Perusahaan Manufaktur Yang Terdaftar Di Bursa Efek Indonesia Tahun 2013-2017)

\author{
Chyntya Lisnawati ${ }^{1}$, Nurzi Sebrina ${ }^{2}$ \\ 1) Jurusan Akuntansi Fakultas Ekonomi Universitas Negeri Padang \\ 2)Jurusan Akuntansi Fakultas Ekonomi Universitas Negeri Padang \\ *Korespodensi: Lisnawaticintia@gmail.com
}

\begin{abstract}
This study aims to examine earnings management behavior is based on the company life cycle. This study is classified as comparative research. The population in this study are manufacturing companies listed on the Indonesian Stock Exchange period of 2013 to 2017. By using purposive sampling method, there were 61 companies as the research's sample. Earning managements is measured through accrual earnings management and real earning management. Company life cycle is measured using the company cash flow. The type of data used is secondary data obtained from www.idx.co.id and used is descriptive analysis. The results of this study indicate that:1) company in the start up, growth, mature and decline stages tend to use real earning management, 2)there is no decrease in earnings management as the life cycle changes from start up, growth, mature and decline stages.
\end{abstract}

Keywords: earnings management; accrual earning management; real earning management; company life cycle.

How to cite (APA $6^{\text {th }}$ style)

Lisnawati, C., \& Sebrina,N. (2019). Perilaku Manajemen Laba Berdasarkan Siklus Hidup Perusahaan (Studi Empiris pada Perusahaan Manufaktur yang Terdaftar di Bursa Efek Indonesia Tahun 2013-2017). Jurnal Eksplorasi Akuntansi, 1(3), Seri D, 13071321.

\section{PENDAHULUAN}

Laporan keuangan adalah merupakan salah satu alat penting sebagai bahan pertimbangan untuk pengambilan keputusan ekonomi oleh suatu perusahaan. Laporan keuangan digunakan pihak manager guna menginformasikan pertanggungjawaban mereka mengenai penggunaan dan pengelolaan sumber daya yang dipercaya untuk tercapainya tujuan perusahaan. Laporan keuangan harus menyajikan informasi yang berguna bagi investor, calon investor, kreditor, serta keputusan lain yang rasional.

Informasi yang termuat di dalam laporan keuangan haruslah tepat serta bermanfaat dalam memenuhi tujuannya agar tidak menyesatkan maupun merugikan stakeholders untuk proses pengambilan keputusan. Informasi yang diperlukan oleh pihak stakeholders dalam laporan keuangan salah satunya ialah informasi terkait laba. Laba ialah keuntungan atas upaya yang dilakukan perusahaan dalam menghasilkan serta menjual barang dan jasanya (Suwardjono,2010). Informasi laba sebagai suatu bagian dari sebuah laporan keuangan 
seringkali menjadi target rekayasa melalui tindakan opurtunis oleh pihak manajemen untuk memaksimumkan kepentingannya, dimana mana hal ini dapat merugikan pemegang saham maupun investor. Perilaku manajemen untuk mengatur laba sesuai dengan keinginannya tersebut dikenal dengan istilah manajemen laba (earnings management).

Scott (2000) menjelaskan manajemen laba sebagai suatu pemilihan terkait kebijakan akuntansi oleh pihak manajer dari standar akuntansi yang ada yang dapat meningkatkan utilitas dan nilai pasar perusahaan. Scoot menjelaskan bahwa manajemen laba dapat dilihat melalui dua perspektif perilaku yaitu perspektif opurtunitis manajer dan perspektif efficient contracting. Manajemen laba dalam penelitian ini akan dilihat sebagai sebuah bentuk tindakan opportunistik oleh manajer dalam perusahaan. Perkembangan penelitian manajemen laba sendiri kemudian mendapati bahwa manajemen laba dapat dilakukan melalui 2 pendekatan yang berbeda yakni manajemen laba akrual yang ditunjukkan dengan adanya discretionary accrual (diskresionari akrual) dan juga manajemen laba rill yang dilakukan dengan tindakan manajemen yang menyimpang dari praktik bisnis normal yang dilakukan dengan tujuan untuk memperoleh target laba (Roychowndhury: 2006).

Manajemen laba merupakan salah satu topik penelitian yang menarik untuk diteliti, terlebih lagi karena pola manajemen laba yang mulai bergeser dari manajemen laba akrual ke manajemen laba rill setelah periode Sarbanes-Oxley (SOX). Dimana hal ini menunjukkan bahwa strategi perusahaan dalam mencapai target laba telah berpindah dari strategi manajemen laba berbasis akrual ke manajemen laba rill. Pergeseran dari manajemen laba akrual ke manajemen laba rill dipengaruhi oleh beberapa faktor. Pertama, manipulasi melalui akrual sering dijadikan pusat pengamatan serta inspeksi oleh pihak auditor dan regulator dibanding keputusan mengenai penentuan harga dan produksi perusahaan. Kedua, Manipulasi akrual dapat menjadi suatu tindakan yang beresiko karena perusahaan yang memiliki fleksibilotas terbatas dalam mengatur akrual (Graham, et al., 2005).

Penelitian mengenai manajemen laba pada umumnya hanya membahas terkait faktor yang menyebabkan terjadinya manajemen laba maupun keterkaitan antara manajemen laba dengan asimetri dan kinerja perusahaan. Penelitian yang mengkaji mengenai bagaimana perusahaan memilih metode manajemen laba yang digunakan sendiri masih jarang dilakukan. Penelitian ini akan melihat bagaimana sebuah perusahaan memilih metode manajemen laba berdasarkan siklus hidup perusahaan yang dialaminya. Siklus hidup perusahaan sendiri dapat diartikan sebagai perkembangan perusahaan yang ditandai dengan adanya tahapan tahapan yang dilalui oleh setiap perusahaan. Siklus hidup perusahaan memiliki karakteristik yang berbeda pada masing masing tahapannya sehingga akan mempengaruhi keputusan manajemen laba yang dilakukan oleh perusahaan.

Penelitian terdahulu yang menghubungkan laba dengan siklus hidup belum menunjukkan hasil yang lengkap mengenai pemilihan manajemen laba berdasarkan siklus hidupnya. Penelitian Sri Hastuti (2006) menemukan bahwa terjadi penurunan manajemen laba dari tahapan growth ke tahapan mature, tetapi tidak terdapat penurunan dari tahapan mature ke stagnant. Pachariyanok (2015) memberikan bukti empiris mengenai pemilihan antara manajemen laba dimana penelitian membuktikan manajemen pada tahapan start up dan growth menggunakan manajemen laba akrual. Berdasarkan hasil penelitian tersebut penulis tertarik untuk mengangkat masalah ini dalam suatu penelitian yang bertujuan untuk memperoleh bukti empiris yang mempengaruhi keputusan perusahaan dalam pemilihan perilaku manajemen laba diantara manajemen laba akrual dan manajemen laba rill berdasarkan siklus hidup perusahaan.

Penelitian ini merupakan pengembangan dari penelitian terdahulu, dimana penulis memasukkan unsur siklus hidup perusahaan yang diklasifikasikan sesuai dengan metode Dickinson (2007). Penelitian ini bertujuan untuk memberikan bukti empiris mengenai 
bagaimana perilaku manajemen laba berdasarkan siklus hidup pada perusahaan manufaktur yang terdaftar di Bursa Efek Indonesia tahun 2013-2017.

\section{REVIU LITERATUR DAN HIPOTESIS}

\section{Teori Keagenan}

Teori agensi memaparkan bahwa hubungan agensi muncul saat satu orang atau lebih (principal) memperkerjakan pihak lain (agent) guna memberikan suatu jasa dan kemudian mendelegasikan wewenang pengambilan keputusan kepada agent tersebut (Govindarajan 2005). Teori ini muncul karena adanya suatu kontrak yang terjadi diantara pihak principal dan agent untuk pembuatan keputusan.

Teori keagenan mendeskripsikan hubungan diantara pemegang saham (stakeholders) sebagai prinsipal dan manajemen sebagai agent. Konsep manajemen laba sendiri menggunakan pendekatan teori keagenan. Teori keagenan berfokus pada dua pihak yakni agent dan principal yang masing masing berusaha untuk memaksimalkan kepentingan dirinya sendiri, hal ini akan menyebabkan terjadinya konflik kepentingan. Pihak principal akan termotivasi untuk mensejahterahkan dirinya melalui profitabiltas yang selalu meningkat. Pihak manajemen akan termotivasi memaksimalkan pemenuhan kebutuhan ekonomis serta psikologinya seperti dalam hal memperoleh investasi, pinjaman, maupun kontrak kompensasi dan bonus.

Teori agensi menjelaskan bahwa agent dan principal ingin memaksimalkan keuntunganya dengan informasi yang mereka miliki. Agent mempunyai informasi yang lebih banyak mengenai perusahaan secara keseluruhan dibandingkan dengan pemegang saham . Hal inilah yang mengakibatkan adanya ketidakseimbangan informasi diantra principal dan agent. Ketidakseimbangan informasi ini memicu manajer untuk melakukan tindakantindakan oportunistik salah satunya dengan melakukan manajemen laba.

\section{Manajemen Laba}

Manajemen laba adalah sebuah tindakan oleh manajemen guna memilih kebijakan akuntansi dari suatu standar tertentu dengan maksud memaksimalkan kesejahteraan pihak manajemen. Schoot (2006) mendefinisikan manajemen laba sebagai suatu tindakan manajemen untuk memilih kebijakan akuntansi dari suatu standar tertentu dengan tujuan memaksimalkan kesejahteraan pihak manajemen. Sulistyanto (2008) mendefinisikan bahwa manajemen laba sebagai upaya manajer perusahaan dalam mengintervensi atau mempengaruhi informasi dalam laporan keuangan dengan tujuan untuk mengelabui stakeholder yang ingin mengetahui kinerja dan kondisi perusahaan.

Manajemen laba menjadi salah satu faktor yang bisa mengurangi kredibilitas dari laporan keuangan. Manajemen laba akan menambah bias dalam laporan keuangan sehingga dapat mengganggu pemakai laporan keuangan yang mempercayai angka laba hasil rekayasa tersebut sebagai angka laba tanpa rekayasa. Manajemen laba akan membuat laba tidak sesuai dengan realitas ekonomi yang ada, tetapi lebih karena keinginan manajemen untuk memperlihatkan sedemikian rupa sehingga kinerjanya dapat terlihat baik.

Manajemen laba dapat terjadi karena pihak manajer yang memiliki fleksibilitas untuk memilih diantara beberapa alternatif pencatatan transaksi dalam perlakuan akuntansi. Ini adalah esensi dari manajemen laba yaitu suatu kemampuan untuk "memanipulasi" pilihan pilihan tersedia dan mengambil pilihan yang tepat guna dapat mencapai tingkat laba yang diharapkan. Manajemen laba diklasifikasikan menjadi dua jenis yaitu manajemen laba akrual dan manajemen laba rill. 


\section{Manajemen Laba Akrual}

Manajemen laba akrual adalah manajemen laba yang terjadi ketika manajer memanipulasi laba akrual yang tidak memiliki kaitan dengan cash flow. Teknik manipulasi ini sendiri merupakan hasil dari penerapan sistem akuntansi akrual. Akuntansi akrual sendiri memerlukan estimasi serta pertimbangan yang mengakibatkan manajer memiliki kebebasan untuk menentukan dan menetapkan kebijakan akuntansi dimana kebebasan ini juga memungkinkan manajer untuk mempercantik laporan keuangan juga mengelola pendapatan. Sahabu (2009) menjelaskan bahwa manajemen laba akrual merupakan manipulasi yang mengendalikan transaksi transaksi akrual yang hanya bisa dilakukan pada akhir periode. Manajemen laba akrual dilakukan pada akhir periode ketika manajer telah mengetahui laba sebelum direkayasa sehingga dapat mengetahui berapa besar manipulasi yang diperlukan agar target laba yang diinginkan tercapai.

\section{Manajemen Laba Rill}

Manajemen melalui aktivitas rill adalah teknik manipulasi laba yang dilakukan oleh manajemen melalui aktivitas perusahaan sehari hari selama periode akuntansi. Manajemen laba riil adalah tindakan-tindakan manajemen yang menyimpang dari praktek bisnis normal dan dilakukan dengan tujuan utama untuk mencapai target laba (Roychowdhury, 2006; Cohen dan Zarowin, 2010).

Manajemen laba riil dapat dilakukan melalui 3 (tiga) cara yaitu: 1) Manipulasi penjualan agar meningkatkan penjualan secara temporer dalam periode tertentu melalui pemberian diskon atas harga produk secara berlebihan maupun pemberian syarat kredit yang lunak, 2) Produksi berlebihan yang merupakan teknik manajemen laba dengan melakukan produksi secara besar-besaran yang akan mengakibatkan penurunan harga pokok penjualan menurun serta 3) Penurunan biaya diskresioner yang merupakan penurunan terhadap biayabiaya yang tidak memiliki hubungan yang akurat dengan output dimana perusahaan dapat mengurangi biaya diskresioner yang dilaporkan untuk meningkatkan laba.

\section{Siklus Hidup Perusahaan}

Siklus hidup perusahaan ialah perkembangan perusahaan yang ditandai dengan adanya tahapan-tahapan yang dilewati oleh setiap perusahaan. Siklus hidup perusahaan secara umum dapat diklasifikasikan menjadi tahap start up, growth, mature, stagnan dan decline. Setiap tahapan pada siklus hidup perusahaan akan memiliki karakteristik tertentu yang berpengaruh terhadap kinerja maupun kebijakan yang diambil oleh perusahaan. Ada beberapa metode pengklasifikasian siklus hidup perusahaan. Salah satunya adalah metode yang dipakai oleh Dickinson (2007).

Pada penelitian ini penulis akan menggunakan metode yang telah dikembangkan oleh Dickinson (2007) yaitu berdasarkan cash flow patterns. Dickinson (2007) mengklasifikasikan siklus hidup menggunakan pola arus kas (cash flow patterns), alasannya karena pola arus kas bisa menangkap konstruk dari siklus hidup perusahaan dengan membuktikan bahwa arus kas menangkap hasil keuangan di tahapan siklus hidup yang berbeda-beda.

\section{Penelitian Terdahulu}

Penelitian terdahulu yang meneliti mengenai perilaku manajemen laba berdasarkan siklus hidup adalah penelitian yang dilakukan oleh Sri Hastuti (2011), Mitha Dwi Restuti (2015), Pachariyanok (2015), Carolyn Lukita (2016) serta Theresia dan Imam Ghozali (2017).

\section{Perusahaan pada tahap start up cenderung menggunakan manajemen laba akrual}

Perusahaan ditahapan start up akan berusaha menampilkan kinerja yang baik agar investor tertarik dalam memberikan pendanaan. Akan tetapi pada tahapan ini, Perusahaan baru 
mempunyai volumen penjualan awal yang sedikit serta memiliki cashflow yang rendah sehingga perusahaan cenderung melakukan manajemen laba. Pada tahapan ini perusahaan akan cenderung menggunakan manajemen laba akrual dibanding manajemen laba rill dikarenakan perusahaan fokus terhadap laba jangka pendek untuk kegiatan investasi serta tidak memungkinkanya perusahaan melakukan pemotongan pada pengeluaran diskresioner yang diperlukan untuk inovasi dan pemasaran. Perusahaan juga tidak memungkinkan untuk melakukan manipulasi penjualan dan overproduction sehingga perusahaan akan menggunakan manajemen laba akrual. Hasil penelitian Pachariyanok (2015) memberikan bukti empiris terkait hal ini dimana penelitian menemukan perusahaan pada tahapan start up cenderung melakukan manajemen laba akrual.

H1: Perusahaan pada tahapan start up cenderung menggunakan manajemen laba akrual.

Perusahaan pada tahapan growth cenderung menggunakan manajemen laba rill.

Perusahaan pada tahapan growth telah memiliki cashflow yang cukup tinggi seiring produk yang mulai dikenal pasar namun perusahaan masih harus menarik perhatian investor guna pengembangan bisnis. Perusahaan pada tahapan growth ini umumnya membutuhkan dana yang besar dari investor untuk perkembangan serta kemajuan perusahaan, hal ini akan memotivasi manajer untuk menampilkan laba yang baik. Perusahaan di tahap ini memungkinkan menggunakan manajemen laba rill dan manajemen laba akrual guna menaikan laba perusahaan, namun manajemen aba akrual sering dijadikan pusat pengamatan serta inspeksi oleh auditor dibanding keputusan tentang penentuan harga dan produksi sehingga manajer akan cenderung menggunakan manajemen laba rill. Hasil penelitian Cohen dan Zarawin (2010) menemukan bukti empiris bahwa perusahaan mengurangi pengeluaran diskresioner pada saat tahun pelaksanaan seasoned equit offerings (SEO).

$\mathbf{H}_{2}$ : Perusahaan pada tahapan growth cenderung menggunakan manajemen laba rill

\section{Perusahaan pada tahapan mature cenderung menggunakan manajemen laba rill.}

Perusahaan di tahapan mature akan mengalami puncak penjualan karena pangsa pasar yang semakin luas. Umumnya perusahaan melakukan manajemen laba agar menjaga kepercayaan investor serta kreditor ataupun untuk mencapai target laba guna mendapatkan kompesasi. Manajemen laba rill dapat menjadi alternative karena perusahaan telah mengurangi pengembangan ataupun proyek baru dimana kondisi ini digunakan untuk melakukan manipulasi manajemen laba rill melalui pengurangan biaya diskresioner. Carolin (2016) menemukan bahwa perusahaan di tahapan mature melakukan manajemen laba rill melalui pengurangan pada biaya diskresioner.

H3: Perusahaan pada tahap mature cenderung menggunakan manajemen laba rill

\section{Perusahaan pada tahapan decline cenderung menggunakan manajemen laba rill}

Perusahaan di dalam tahapan ini melakukan manajemen laba guna mempertahankan laba pada saat penjualan telah mulai mengalami penurunan yang stabil akibat adanya pesaing baru. Perusahaan di tahap decline umumnya mengalami penurunan sehingga manajer melakukan manajemen laba dengan motivasi memperoleh laba jangka pendek agar terhindar dari penurunan harga saham dan restrukturisasi manajer. Carolyn (2016) menemukan perusahaan di tahapan decline melakukan manipulasi melalui biaya produksi.

H4: Perusahaan pada tahap decline cenderung menggunakan manajemen laba rill

\section{Perilaku manajemen laba pada perubahan tahapan siklus hidup perusahaan}

Perusahaan akan mengalami tahapan selama hidupnya dimulai dari tahapan start up, growth, mature dan decline. Pada tahapan start up dan growth perusahaan tersebut akan berusaha menampilkan laba yang baik guna menarik perhatian investor. akan tetapi hal ini mengalami 
kendala dikarenakan perusahaan masih kurang memiliki pengalaman dan masih minimnya kepercayaan investor untuk berinvestasi, oleh karena itu manajemen laba biasanya akan dilakukan secara besar besaran di tahapan ini. Perusahaan dalam tahapan mature yang telah melakukan persaingan pasar dengan perusahaan sejenis sehingga laba cenderung mengalami penurunan. Tahapan inilah perusahaan melakukan perataan laba agar laba tetap terlihat stabil. Perusahaan ditahapan decline sudah stabil dan fluktuasi laba tidak signifikan sehingga kecil kemungkinan melakukan manajeme laba.

Manajemen laba umunya cenderung menurun pada setiap tahapanya karena semakin tinggi siklus hidup perusahaan maka semakin baiknya pengendalian internal yang dimiliki oleh perusahaan. Perusahaan di tahapan mature dan decline umumnya telah memiliki sistem pengendalian internal yang baik serta auditor internal ataupun dewan komisaris yang sudah kompeten. Penerapan sistem pengendalian yang ketat akan membatasi pihak manajemen dalam melakukan manajemen laba. Hastuti (2006) menunjukan bahwa manajemen laba pada tahapan stagnant lebih rendah daripada perusahaan di tahapan mature. Anggaraini (2012) menyatakan bahwa pengaruh siklus hidup terhadap manajemen laba menunjukan hasil yang negative dimana semakin tinggi siklus hidup maka semakin rendah manajemen laba yang dilakukan.

Hs: Terdapat maanajemen laba yang semakin rendah seiring dengan perubahan siklus hidup perusahaan dari tahapan start up, growth, mature dan decline.

\section{Kerangka Konseptual}

Berdasarkan pengembangan hipotesis, maka kerangka konseptual penelitian ini dapat dilihat pada Gambar 1.

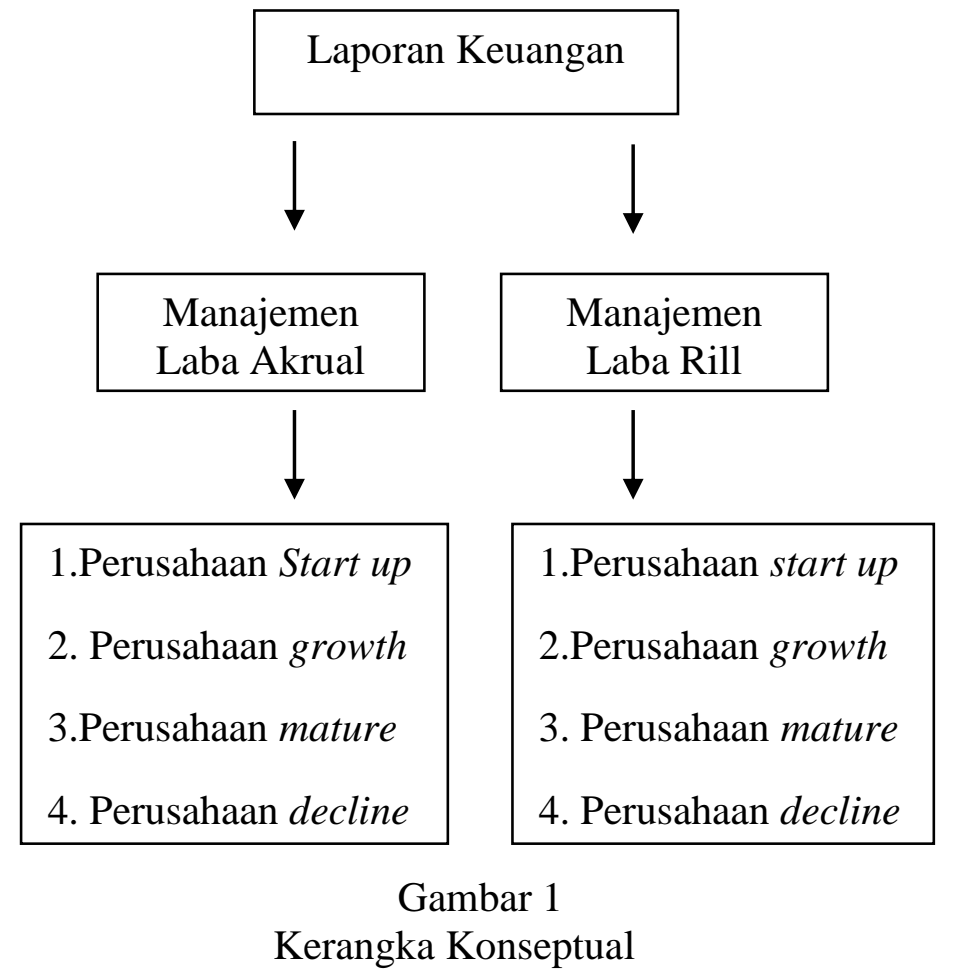

\section{METODE PENELITIAN}

Jenis penelitian ini ialah penelitian kuantitatif komparatif. Jenis data yang dipakai adalah data sekunder. Data yang digunakan dalam penelitian ini adalah laporan keuangan perusahaan manufaktur yang dipublikasikan untuk tahun 2013-2017. Sumber data berasal dari situs resmi Bursa Efek Indonesia yaitu www.idx.co.id. 
Populasi dalam penelitian ini adalah seluruh perusahaan manufaktur yang terdaftar di Bursa Efek Indonesia (BEI) selama periode pengamatan yakni tahun 2013-2017. Teknik pengambilan sampel adalah purposive sampling. Kriteria yang digunakan dalam pemilihan sampel ialah perusahaan manufaktur yang terdaftar di Bursa Efek Indonesia, perusahaan yang memiliki data lengkap terkait variabel yang digunakan untuk penelitian, serta menyajikan mata uang dalam rupiah ( $\mathrm{Rp}$ ) yang konsisten selama periode pengamatan, yaitu tahun 20132017. Sehingga didapatkan sampel untuk penelitian sebanyak 61 perusahaan.

Tabel 1

Kriteria Penentuan Sampel

\begin{tabular}{|c|l|c|}
\hline No. & \multicolumn{1}{|c|}{ Keterangan } & Jumlah Perusahaan \\
\hline 1. & $\begin{array}{l}\text { Perusahaan manufaktur yang terdaftar di BEI } \\
\text { tahun 2016 }\end{array}$ & $(41)$ \\
\hline 2. & $\begin{array}{l}\text { Perusahaan manufaktur yang tidak lengkap } \\
\text { laporan tahunan di BEI periode 2013-2016 }\end{array}$ & $(31)$ \\
\hline 3. & $\begin{array}{l}\text { Perusahan manufaktur yang tidak memiliki data } \\
\text { lengkap terkait variabel-variabel penelitian }\end{array}$ & $(26)$ \\
\hline 4. & $\begin{array}{l}\text { Perusahaan manufaktur yang menyajikan laporan } \\
\text { keuangan tidak dalam rupiah periode 2013-2016 }\end{array}$ & $\mathbf{6 1}$ \\
\hline \multicolumn{2}{|c|}{ Total sampel yang digunakan dalam penelitian } \\
\hline
\end{tabular}

\section{Variabel Penelitian \& Pengukurannya}

\section{Manajemen Laba Akrual}

Pengukuran manajemen laba akrual ditunjukan dengan discretionary accrual yang dihitung menggunakan Modified Jones Model, dengan persamaan berikut:

a. Nilai Total Akrual $=\mathrm{Ni}-\mathrm{CF}$

b. Nilai regresi linear sederhana dengan model:

$$
\left.\frac{\mathrm{TAC}_{\mathrm{it}}}{\mathrm{TA}_{\mathrm{it}-1}}=\beta_{1} \frac{[1]}{\mathrm{TA}_{\mathrm{it}-1}}+\beta_{2} \frac{\left[\Delta \text { Sales }_{\text {it }}\right.}{\mathrm{TA}_{\mathrm{it}-1}}\right]+\beta_{3}\left[\frac{\left.\mathrm{PPE}_{\mathrm{it}}\right]}{\mathrm{TA}_{\mathrm{it}-1}}+€\right.
$$

c. mencari nondiscretionary accrual (NDTA)

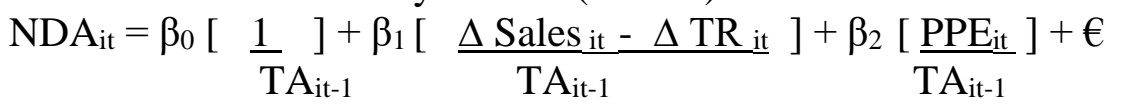

d. Menghitung Nilai discretionary accrual

$\mathrm{DAC}_{\mathrm{it}}=\underline{\mathrm{TAC}_{\mathrm{It}}}-\mathrm{NDAC}_{\mathrm{it}}$

$\mathrm{TA}_{\mathrm{it}-1}$

Manajemen laba akrual ditunjukkan melalui discretionary accrual. Nilai manajemen laba yang dipakai dalam penelitian ini merupakan nilai absolute dari discreetionary accrual yang lebih besar dari nol, tanpa memperhatikan cara perusahaan melakukan manajemen laba baik dengan cara menaikkan maupun menurunkan laba.

\section{Manajemen Laba Rill}

\section{a. Manipulasi aktivitas rill melalui arus kas operasi}

Langkah awal yang dilakukan sebelum masuk dalam pengujian hipotesis maka akan dilakukan regresi guna mencari arus kas kegiatan operasi normal. Model regresi untuk mencari arus kas kegiatan operasi normal mereplikasi dari penelitian Roychowdhury (2006) sebagai berikut:

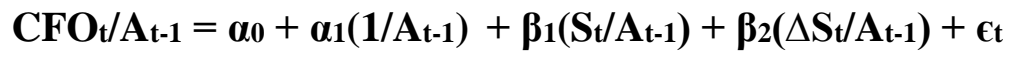


Keterangan:

$\mathrm{CFO}_{\mathrm{t}} / \mathrm{A}_{\mathrm{t}-1}$ : arus kas kegiatan operasi pada tahun $\mathrm{t}$ yang diskala dengan total aktiva pada tahun $\mathrm{t}-1$.

$\mathrm{S}_{\mathrm{t}} / \mathrm{A}_{\mathrm{t}-1} \quad$ : penjualan pada tahun $\mathrm{t}$ yang diskala dengan total aktiva pada tahun $\mathrm{t}-1$.

$\Delta \mathrm{S}_{\mathrm{t}} / \mathrm{A}_{\mathrm{t}-1} \quad$ : penjualan pada tahun $\mathrm{t}$ dikurangi penjualan pada tahun $\mathrm{t}-1$ yang diskala dengan total aktiva pada tahun $\mathrm{t}-1$.

$\alpha_{0} \quad$ : konstanta.

$\epsilon_{\mathrm{t}} \quad$ : error term pada tahun $\mathrm{t}$.

Oleh karena itu untuk penelitian ini yang akan digunakan adalah arus kas kegiatan operasi abnormal, maka untuk setiap observasi tahun arus kas kegiatan operasi abnormal (ABN_CFO) ialah selisih dari nilai arus kas kegiatan operasi aktual yang diskalakan dengan total aktiva satu tahun sebelum pengujian dikurangi dengan arus kas kegiatan operasi normal yang dihitung dengan menggunakan koefisien estimasi yang diperoleh dari model persamaan di atas.

\section{ABN_CFO $=$ CFOt - CFOt/At-1}

\section{b. Manipulasi aktivitas rill melalui biaya produksi}

Peneliti menggunakan model estimasi untuk biaya produksi normal sebagaimana Roychowdhury (2006) sebagai berikut:

$$
\operatorname{PROD}_{t} / A_{t-1}=\alpha_{0}+\alpha_{1}\left(1 / A_{t-1}\right)+\beta_{1}\left(S_{t} / A_{t-1}\right)+\beta_{2}\left(\Delta S_{t} / A_{t-1}\right)+\beta_{3}\left(\Delta S_{t-1} / A_{t-1}\right)+\epsilon_{t}
$$

\section{Keterangan:}

PROD $_{t} / A_{t-1}$ : biaya produksi pada tahun $t$ yang diskala dengan total aktiva pada tahun $\mathrm{t}-$

1, dimana $\mathrm{PROD}_{\mathrm{t}}=\mathrm{COGS}_{\mathrm{t}}+\Delta \mathrm{INV}_{\mathrm{t}}$

$\alpha\left(1 / A_{t-1}\right) \quad$ : intersep yang diskala dengan total aktiva pada tahun $\mathrm{t}-1$

$\mathrm{S}_{\mathrm{t}} / \mathrm{A}_{\mathrm{t}-1} \quad$ : penjualan pada tahun $\mathrm{t}$ yang diskala dengan total aktiva pada tahun $\mathrm{t}-1$.

$\Delta \mathrm{S}_{\mathrm{t}} / \mathrm{A}_{\mathrm{t}-1} \quad$ : penjualan pada tahun $\mathrm{t}$ dikurangi penjualan pada tahun $\mathrm{t}-1$ yang diskala dengan total aktiva pada tahun $\mathrm{t}-1$.

$\Delta \mathrm{S}_{\mathrm{t}-1} / \mathrm{A}_{\mathrm{t}-1} \quad$ : perubahan penjualan pada tahun $\mathrm{t}-1$ yang diskala dengan total aktiva pada tahun $\mathrm{t}-1$.

$\alpha_{0} \quad$ : konstanta

$\epsilon_{\mathrm{t}} \quad:$ error term pada tahun $\mathrm{t}$.

nilai koefisien estimasi dari persamaan regresi di atas digunakan untuk menghitung nilai biaya produksi normal. Sehingga, biaya produksi abnormal (ABN_PROD) diperoleh dengan cara:

\section{ABN_PROD $=$ PRODt - PROD $/ A_{t-1}$}

\section{c. Manipulasi Aktivitas Riil melalui Biaya Diskresioner}

Pengukuran manajemen laba rill melalui biaya diskresioner abnormal guna menilai kecenderungan perusahaan dalam menggunakan biaya diskresioner abnormal dalam melakukan manajemen laba. Untuk menghitung tingkat normal biaya diskresioner, peneliti menggunakan model regresi berikut yang juga mereplikasi dari penelitian Roychowdhury (2006):

$$
\operatorname{DISEXPt} / A_{t-1}=\alpha_{0}+\alpha_{1}\left(1 / A_{t-1}\right)+\beta\left(S_{t-1} / A_{t-1}\right)+\epsilon_{t}
$$


Keterangan:

DISEXP $\mathrm{t}_{\mathrm{t}} / \mathrm{A}_{\mathrm{t}-1}$ : biaya diskresioner pada tahun $\mathrm{t}$ yang diskala dengan total aktiva tahun $\mathrm{t}-1$ $\alpha\left(1 / \mathrm{A}_{\mathrm{t}-1}\right) \quad$ : intersep yang diskala dengan total aktiva pada tahun $\mathrm{t}-1$ dengan tujuan supaya biaya diskresioner tidak memiliki nilai 0 ketika penjualan dan lag penjualan bernilai 0.

$\mathrm{S}_{\mathrm{t}-1} / \mathrm{A}_{\mathrm{t}-1} \quad$ : penjualan pada tahun $\mathrm{t}-1$ yang diskala dengan total aktiva pada tahun

Nilai koefisien estimasi dari persamaan regresi di atas akan digunakan untuk menghitung nilai biaya diskresioner normal. Sehingga, biaya diskresioner abnormal (ABN_DISEXP) diperoleh melalui cara yang sama seperti arus kas kegiatan operasi dan biaya produksi yaitu dengan mengurangkan nilai biaya diskresioner aktual yang diskalakan dengan total aktiva satu tahun sebelum periode pengujian dengan biaya diskresioner normal yang dihitung dengan menggunakan koefisien estimasi dari model persamaan di atas.

\section{ABN_DISEXP $=$ DISEXPt - DISEXPt/At-1}

\section{Siklus Hidup Perusahaan}

Metode pengklasifikasian siklus hidup yang penulis gunakan dalam penelitian ini yaitu berdasarkan cash flow patterns mengacu pada model yang dikembangkan oleh Dickinson. Dickinson (2007) mengklasifikasikan siklus hidup perusahaan dengan menggunakan pola arus kas (cash flow patterns), alasannya karena pola arus kas dapat menangkap konstruk dari siklus hidup perusahaan dengan membuktikan bahwa arus kas menangkap hasil keuangan di tahapan siklus hidup yang berbeda-beda, dengan kata lain, pola arus kas dapat digunakan sebagai proxy untuk siklus hidup perusahaan.

Tabel 2:

Klasifikasi Siklus Hidup Perusahaan

\begin{tabular}{|l|c|c|c|c|}
\hline Jenis arus kas & Start-Up & Growth & Mature & Decline \\
\hline Operasi & $(-)$ & $(+)$ & $(+)$ & $(-)$ \\
\hline Investasi & $(-)$ & $(-)$ & $(-)$ & $(+)$ \\
\hline Pendanaan & $(+)$ & $(+)$ & $(-)$ & $(+/-)$ \\
\hline
\end{tabular}

Perusahaan yang menjadi sampel dalam penelitian ini akan dikelompokkan kedalam tahap startup, growth, mature dan decline berdasarkan kriteria diatas. Jika arus kas operasi perusahaan bernilai negatif, arus kas investasinya memiliki negatif, serta arus kas pendanaannya bernilai positif, maka perusahaan tersebut dikelompokkan ke dalam tahap startup. Apabila arus kas operasi perusahaan bernilai positif, arus kas investasinya memiliki nilai negatif, dan arus kas pendanaannya bernilai positif, maka perusahaan tersebut dikelompokkan ke dalam tahap growth. Kemudian jika arus kas operasi perusahaan memiliki nilai positif, arus kas investasinya bernilai negatif, kemudian arus kas pendanaannya bernilai negatif, maka perusahaan tersebut dikelompokkan ke dalam tahap mature. Perusahaan masuk ke dalam tahap decline, jika arus kas operasi perusahaan memiliki nilai negatif, arus kas investasinya bernilai positif, serta arus kas pendanaannya bernilai negatif / positif.

\section{HASIL DAN PEMBAHASAN}

Pada bagian ini mendeskripsikan hasil pengujian dari nilai masing masing manajemen laba akrual dan manajemen laba rill dalam tahapan siklus hidup yang berbeda. Penelitian terlebih dahulu akan menghitung masing masing nilai dari variabel penelitian yakni manajemen laba akrual dan manajemen laba rill. Penelitian ini menguji hipotesis dengan membandingkan mean manajemen laba akrual dan manajemen laba rill pada masing masing tingkatan siklus 
hidup. Pengujian hipotesis dalam penelitian ini ditunjukkan guna menguji perbedaan serta kecenderungan pemilihan manajemen laba berdasarkan pada perbedaan siklus hidup perusahaan. Berikut hasil perhitungan mean manajemen laba akrual dan manajemen laba rill:

Tabel 3

Perhitungan Mean Manajemen Laba Akrual dan Manajemen Laba Rill Perusahaan Manufaktur tahun 2013-2017

\begin{tabular}{|c|c|c|c|c|c|c|}
\hline \multirow{2}{*}{} & \multirow{2}{*}{} & \multirow{2}{*}{ AEM } & \multicolumn{4}{c|}{ REM } \\
\cline { 4 - 7 } & & & CFO & PROD & DISK & TOTAL \\
\hline \multirow{3}{*}{ START UP } & TERTINGGI & $\mathbf{0 . 2 1 0}$ & 0.397 & 0.553 & 0.174 & $\mathbf{0 . 9 4 7}$ \\
\cline { 2 - 7 } & TERENDAH & $\mathbf{0 . 0 0 3}$ & 0.057 & 0.014 & 0.001 & $\mathbf{0 . 0 9 6}$ \\
\cline { 2 - 7 } & RATA RATA & $\mathbf{0 . 0 8 6}$ & 0.162 & 0.264 & 0.044 & $\mathbf{0 . 4 7 1}$ \\
\hline \multirow{3}{*}{ GROWTH } & TERTINGGI & $\mathbf{0 . 4 3 0}$ & 0.245 & 0.774 & 0.205 & $\mathbf{1 . 2 2 3}$ \\
\cline { 2 - 7 } & TERENDAH & $\mathbf{0 . 0 0 2}$ & 0.009 & 0.014 & 0.003 & $\mathbf{0 . 0 2 4}$ \\
\cline { 2 - 7 } & RATA RATA & $\mathbf{0 . 0 5 7}$ & 0.043 & 0.148 & 0.038 & $\mathbf{0 . 2 2 8}$ \\
\hline \multirow{3}{*}{ DECLINE } & TERTINGGI & $\mathbf{0 . 3 6 7}$ & 0.206 & 0.518 & 0.283 & $\mathbf{0 . 7 7 1}$ \\
\cline { 2 - 7 } & TERENDAH & $\mathbf{0 . 0 0 0 2}$ & 0.001 & 0.002 & 0.001 & $\mathbf{0 . 0 0 1}$ \\
\cline { 2 - 7 } & RATA RATA & $\mathbf{0 . 0 5 3}$ & 0.015 & 0.100 & 0.040 & $\mathbf{0 . 1 5 5}$ \\
\cline { 2 - 7 } & TERTINGGI & $\mathbf{0 . 4 3 0}$ & 0.245 & 0.774 & 0.283 & $\mathbf{1 . 2 2 3}$ \\
\cline { 2 - 7 } & TERENDAH & $\mathbf{0 . 0 0 0}$ & 0.001 & 0.058 & 0.012 & $\mathbf{0 . 0 0 1}$ \\
\cline { 2 - 7 } & RATA RATA & $\mathbf{0 . 1 4 2}$ & 0.097 & 0.260 & 0.088 & $\mathbf{0 . 4 1 0}$ \\
\hline
\end{tabular}

Sumber data sekunder olahan tahun 2019.

\section{PEMBAHASAN}

\section{Perusahaan pada tahap start up cenderung menggunakan manajemen laba akrual}

Hipotesis pertama dalam penelitian ini ialah perusahaan pada tahap start up cenderung menggunakan manajemen laba akrual. Variabel manajemen laba akrual dan manajemen laba rill akan dihitung serta dilihat dari nilai rata rata (mean) masing masing guna melihat kecenderungan penggunaan manajemen laba rill atau manajemen laba akrual. Berdasarkan hasil penelitian terhadap perusahaan yang berada di tahapan start up ditemukan bahwa Hipotesis $\left(\mathrm{H}_{1}\right)$ ditolak, hal ini menunjukkan bahwa perusahaan pada tahap start up cenderung melakukan manajemen laba rill dimana mean manajemen laba rill lebih besar dibanding mean manajemen laba akrual.

Pada tahapan start up menunjukan nilai mean manajemen laba rill yang lebih besar dibandingkan mean manajemen laba akrual, hal ini menjelaskan bahwa pada tahapan start up perusahaan lebih banyak menggunakan manajemen laba rill baik melalui manipulasi cashflow, manipulasi biaya diskresioner maupun manipulasi produksi. Pada tahapan start up manipulasi produksi memiliki nilai tinggi yang berarti perusahaan melakukan manipulasi biaya produksi, yaitu perusahaan melakukan produksi secara berlebihan ataupun memproduksi barang di atas level normal produksi perusahaan. Jumlah produksi yang berlebihan akan membuat biaya tetap per unit dari produk menjadi lebih rendah. Strategi ini dapat menurunkan harga pokok penjualan yang secara langsung akan meningkatkan laba perusahaan, sehingga kinerja perusahaan dapat dinilai baik. Perusahaan pada tahapan start up akan terdorong melaporkan laba yang tinggi guna menarik perhatian pihak investor untuk pengembangan perusahaan, sehingga perusahaan melakukan manajemen laba, salah satunya melalui abnormal produksi. 
Hasil penelitian ini tidak sejalan dengan penelitian Pachariyanok (2015) yang menyimpulkan bahwa perusahaan pada tahapan start up lebih memilih menggunakan manajemen laba akrual. Perusahaan yang berada di tahapan start up memilih menggunakan manajemen laba akrual guna memperoleh target laba jangka pendek. Berdasarkan hasil penelitian, maka dapat disimpulkan perusahaan pada tahapan start up cenderung menggunakan manajemen laba rill.

\section{Perusahaan pada tahap growth cenderung menggunakan manajemen laba rill}

Hipotesis kedua dalam penelitian ini ialah perusahaan pada tahap growth cenderung menggunakan manajemen laba rill. Variabel manajemen laba akrual dan manajemen laba rill akan dihitung serta dilihat dari nilai rata rata (mean) masing masing guna melihat kecenderungan penggunaan manajemen laba rill ataupun manajemen laba akrual. Hasil penelitian sendiri menunjukkan bahwa perusahaan di tahapan growth melakukan manajemen laba baik manajemen laba akrual maupun manajemen laba rill untuk mengatur laba yang dilaporkan. Berdasarkan hasil penelitian terhadap perusahaan yang berada di tahapan growth ditemukan bahwa Hipotesis $\left(\mathrm{H}_{2}\right)$ diterima, hal ini menunjukkan bahwa perusahaan dalam tahapan growth cenderung melakukan manajemen laba rill dimana mean manajemen laba rill lebih besar dibanding mean manajemen laba akrual.

Pada tahapan growth nilai mean abnormal cashflow menunjukkan bahwa perusahaan melakukan manipulasi aktivitas rill melalui arus kas operasi, dimana cara yang dilakukan untuk manipulasi cashflow melalui manajemen penjualan seperti melalui memberikan potongan harga atau pemberian syarat kredit yang lebih ringan. Volume penjualan yang meningkat akan menyebabkan laba tahun berjalan tinggi namun arus kas menurun karena kas yang masuk kecil akibat adanya penjualan kredit dan potongan harga, oleh karena itu aktivitas manajemen penjualan ini menyebabkan arus kas kegiatan operasi periode sekarang menurun dibandingkan tingkat penjualan normal dan pertumbuhan abnormal dari piutang. Pada tahapan growth sendiri hal ini memungkinkan dilakukan seiring produk perusahaan yang mulai dikenal oleh masyarakat sehingga pemberian diskon ataupun pemberian kredit akan menarik perhatian masyarakat dan meningkatkan volume penjualan.

Hasil penelitian sejalan dengan penelitian Carolyn Lukita (2016) yang menyimpulkan bahwa perusahaan pada tahapan growth cenderung melakukan manajemen laba rill melalui biaya diskresioner dengan mengurangi biaya pengembangan dan pengurangan biaya iklan, karena pengurangan biaya tersebut akan dapat menghasilkan laba jangka pendek bagi perusahaan. Hasil penelitian ini tidak sejalan dengan penelitian Mitha Restuti (2015) yang menyimpulkan bahwa perusahaan di tahapan growth cenderung menggunakan manajemen laba akrual dibanding manajemen laba rill. Penelitian membuktikan bahwa perusahaan melakukan manajemen laba akrual dengan menurunkan laba dan juga melakukan manajemen laba rill melalui manipulasi penjualan dan biaya produksi. Berdasarkan hasil penelitian maka dapat disimpulkan perusahaan pada tahap growth cenderung menggunakan manajemen laba rill.

\section{Perusahaan pada tahap mature cenderung menggunakan manajemen laba rill}

Hipotesis ketiga pada penelitian ini adalah perusahaan pada tahap mature cenderung menggunakan manajemen laba rill. Variabel manajemen laba akrual dan manajemen laba rill akan dihitung dan dilihat dari nilai rata rata (mean) masing masing guna melihat kecenderungan penggunaan manajemen laba rill atau manajemen laba akrual. Berdasarkan hasil penelitian terhadap perusahaan yang berada di tahapan mature ditemukan bahwa Hipotesis $\left(\mathrm{H}_{3}\right)$ diterima, hal ini menunjukkan bahwa perusahaan di tahap mature cenderung melakukan manajemen laba rill dimana mean manajemen laba rill lebih besar dibanding mean manajemen laba akrual. 
Pada tahapan mature ditemukan perusahaan menggunakan manajemen laba laba rill juga manajemen laba akrual guna mengatur laba yang dilaporkan. Penelitian menemukan perusahaan tahap mature lebih massive menggunakan manajemen laba rill. Manajemen laba rill yang dilakukan sendiri dapat melalui manipulasi cashflow, manipulasi produksi dan manipulasi biaya diskresioner. Penelitian sendiri menunjukkan mean manipulasi rill tertinggi dilakukan melalui manipulasi biaya diskresioner. Dalam menampilkan laba yang baik perusahaan pada tahapan mature melakukan pengurangan biaya penelitian pengembangan dan biaya iklan. Manipulasi melalui pengurangan biaya diskresioner disini berkaitan dengan perusahaan pada tahapan mature yang mana kebutuhan perusahaan untuk investasi baru dan pengembagan telah menurun, sehingga perusahaan dapat menurunkan biaya diskresioner untuk meningkatkan laba.

Hasil penelitian ini sejalan denga penelitian Mitha Restuti (2015) yang menyimpulkan bahwa perusahaan cenderung melakukan manajemen laba rill meskipun perusahaan tidak terbukti melakukan manipulasi penjualan, manipulasi biaya diskresioner dan manipulasi biaya produksi yang mana hal ini disebabkan oleh sulitnya membedakan manipulasi melalui aktivitas rill dibandingkan dengan keputusan bisnis optimal. Berdasarkan hasil penelitian maka dapat disimpulkan perusahaan pada tahap mature cenderung menggunakan manajemen laba rill.

\section{Perusahaan pada tahap decline cenderung menggunakan manajemen laba rill}

Hipotesis keempat dalam penelitian ini adalah perusahaan pada tahap decline cenderung menggunakan manajemen laba rill. Variabel manajemen laba akrual dan manajemen laba rill akan dihitung dan dilihat dari nilai rata rata (mean) masing masing guna melihat kecenderungan penggunaan manajemen laba rill atau manajemen laba akrual. Berdasarkan hasil penelitian terhadap perusahaan yang berada di tahapan decline ditemukan bahwa Hipotesis $\left(\mathrm{H}_{4}\right)$ diterima, hal ini menunjukkan bahwa perusahaan pada tahap decline cenderung melakukan manajemen laba rill dimana mean manajemen laba rill lebih besar dibanding mean manajemen laba akrual.

Pada tahap decline aktivitas operasi dan investasi telah mulai mengalami penurunan, dimana perusahaan tidak lagi memerlukan pendanaan yang besar (Hanafi,2003). Namun perusahaan berupaya mempertahankan laba yang diperoleh dengan tujuan untuk mempertahankan laba sedangkan aktivitas operasi telah mengalami penurunan, mengakibatkan manajer melakukan manajemen laba rill melalui manipulasi penjualan dan manipulasi biaya discretionary untuk tidak melaporkan penurunan laba yang berarti penurunan kinerja manajemen. Hasil penelitian ini sejalan dengan penelitian Carolyn Lukita (2016) yang menyimpulkan bahwa perusahaan melakukan manipulasi melalui biaya produksi. Perusahaan melakukan produksi secara berlebihan untuk menurunkan harga pokok penjualan sehingga laba akan meningkat. Berdasarkan hasil penelitian maka dapat disimpulkan perusahaan pada tahap decline cenderung menggunakan manajemen laba rill.

\section{Terdapat manajemen laba yang semakin menurun seiring perubahan siklus hidup perusahaan dari tahapan start up, growth, mature dan decline.}

Pengujian hipotesis 5 dilakukan dengan melihat mean manajemen laba pada setiap tahapanya untuk melihat apakah terdapat manajemen laba yang semakin rendah seiring dengan perubahan siklus hidup dari tahapan start up, growth, mature dan decline. Hasil pengujian menunjukkan nilai manajemen laba yang berfluktuasi pada masing masing siklus hidup tersebut. Hasil penelitian tidak menemukan bahwa terdapat manajemen laba yang semakin rendah seiring dengan perubahan siklus hidup perusahaan. Hasil penelitian menunjukkan manajemen laba tertinggi terjadi di tahapan start up. 
Ketika pada tahap start up, perusahaan masih memiliki cash flow yang tidak terlalu tinggi dan biasanya melakukan manajemen laba dengan tingkat yang tinggi untuk menarik investor. Hal ini disebabkan perusahaan membutuhkan dana yang besar untuk mengembangkan dan memajukan usahanya namun terhambat kendala minimnya pengalaman dan kepercayaan investor untuk menginvestasikan dananya. Pada tahap start up, perusahaan juga belum memiliki sistem pengendalian yang ketat karena masih fokus dalam memenuhi kebutuhan pasar, sehingga hal ini memberikan keleluasaan bagi pihak manajer untuk melakukan manajemen laba. Pada tahapan growth sendiri nilai manajemen laba sudah menurun dibandingkan pada tahapan start up. Pada tahapan growth perusahaan telah mulai memiliki cashflow yang cukup seiring dengan produk yang mulai dikenal oleh masyarakat, perusahaan melakukan manajemen laba untuk meningkatkan laba guna pengembangan bisnis.

Perusahaan pada tahapan mature sendiri telah menunjukkan nilai manajemen yang paling rendah diantara semua tahapan siklus yang ada. Dimana pada tahapan mature sendiri telah ditandai oleh perusahaan yang memiliki sistem pengendalian internal yang baik yang akan membatasi pihak manajemen dalam melakukan manajemen laba. Perusahaan yang memiliki pengendalian internal yang ketat maka manajer akan lebih bertindak berhati hati yang mngakibatkan tingkat manajemen laba akan cenderung berkurang.

Perusahaan dalam tahapan mature juga telah memiliki auditor internal serta dewan komisaris yang kompeten sehingga tingkat manajemen laba yang dilakukan akan berkurang. Perusahaan yang berada pada tahapan decline menunjukkan nilai manajemen laba yang kembali meningkat tinggi dibanding tahapan sebelumnya. Tingkat manajemen laba yang meningkat seiring dengan terjadinya penurunan penjualan yang stabil akibat munculnya pesaing baru. Pada tahapan decline sendiri penurunan laba juga terjadi karena adanya kompetisi harga sehingga manajemen cenderung melakukan manajemen laba secara besar guna menaikan laba.

Hasil penelitian ini sepakat dengan penelitian Sri Hastuti (2011) yang menyimpulkan bahwa tidak terdapat perbedaan dan penurunan manajemen laba seiring dengan perubahan siklus hidup. Hasil penelitian menyimpulkan bahwa terdapat manajemen laba pada perusaaan dalam tahapan growth, mature dan stagnant, tetapi tidak terdapat perbedaan perilaku manajemen laba berdasarkan siklus hidup perusahaan. Hasil penelitian ini juga sejalan dengan penelitian Sri Hastuti (2006) yang menunjukan bahwa manajemen laba pada tahapan stagnant lebih rendah daripada tahapan mature. Hal ini dikarenakan perusahaan pada tahap stagnant tidak terlalu membutuhkan pendanaan dari luar sehingga manajemen laba yang dilakukan lebih kecil.

Hasil penelitian ini tidak sejalan dengan penelitian Utari Putri Luty (2017) yang menemukan bahwa manajemen laba pada siklus hidup perusahaan mature lebih tinggi dibandingkan manajemen laba pada tahapan growth. Hasil penelitian ini tidak sejalan dengan Ardinata Setiawan (2018) yang menjelaskan bahwa terdapat pengaruh negatif antara siklus hidup perusahaan terdapat manajemen laba disebabkan karena perusahaan pada tahap growth masih menggunakan control system yang longgar dan akan menjadi ketat bila sudah mencapai pada tahap mature. Hal ini dikarenakan pada tahap mature perusahaan memasuki tahap ketika manajernya mulai berpengalaman. Berdasarkan hasil penelitian maka disimpulkan tidak terdapat penurunan manajemen laba seiring perubahan siklus hidup dari tahapan start up, growth, mature dan decline.

\section{SIMPULAN, KETERBATASAN, DAN SARAN Simpulan}

Berdasarkan analisis atau hasil penelitian ini, dapat disimpulkan bahwa 1) perusahaan pada tahap start up, growth, mature dan decline cenderung menggunakan manajemen laba rill. 2) tidak terdapat penurunan manajemen laba seiring perubahan siklus hidup dari tahapan start 
up, growth, mature dan decline. Implikasi dari hasil penelitian ini menunjukkan bahwa perusahaan dalam tahapan hidup start up, growth, mature dan decline cenderung menggunakan manajemen laba rill.

Kecenderungan penggunaan manajemen laba rill disebabkan oleh beberapa hal seperti penerapan manajemen laba rill yang dapat dilakukan melalui kegiatan sehari hari sementara manajemen laba akrual hanya dapat dilakukan pada akhir periode sehingga hal ini termasuk pada tindakan yang beresiko karena perusahaan memiliki fleksibilitas yang terbatas dalam mengatur akrual. Perusahaan juga lebih banyak menggunakan manajemen laba rill dikarenakan manipulasi akrual lebih sering dijadikan pusat pengamatan atau inspeksi oleh auditor dan regulator daripada keputusan tentang penentuan harga dan produksi.

Infromasi terkait manajemen laba yang dilakukan perusahaan pada tahapan siklus hidup yang berbeda berguna bagi investor untuk menilai dan menggunakan informasi dalam laporan keuangan sehingga imvestor dapat lebih bijak dalam pembuatan keputusan. Implikasi bagi investor agar dapat mempertimbangkan untuk melihat siklus hidup sedang berada di tahapan apa, sehingga bisa menilai dan menggunakan laporan keuangan dengan baik.

\section{Keterbatasan}

Keterbatsan dalam penelitian ini yang pertama ialah penelitian hanya mengambil sampel perusahaan manufaktur, sehingga data penelitian ini tidak dapat mewakili keseluruhan perusahaan pada Bursa Efek Indonesia. Kedua, Tidak semua sampel pada penelitian menyajikan data dalam laporan arus kas dengan lengkap, padahal data tersebut dibutuhkan untuk menentukan tahapan $t$ yang dilalui oleh perusahaan di setiap tahunya.

\section{Saran}

Bagi peneliti selanjutnya diharapkan dapat 1) menggunakan jenis perusahaan yang berbedabeda serta memakai ruang lingkup sampel yang lebih luas. 2) menggunakan sampel yang menyajikan semua elemen data yang dibutuhkan untuk mengukur varibel siklus hidup perusahaan. 3) menambah tahun pengamatan dengan meneliti lebih dari 5 tahun agar hasil yang diperoleh dapat lebih berkualitas

\section{DAFTAR PUSTAKA}

Anggraini, 2012. "Pengaruh Siklus Hidup dan Ukuran Perusahaan terhadap Manajemen laba". Skripsi. Universitas Brawijaya: Malang.

Cohen et al. 2008. " Real and accrual based and real earning management in the pre and post Sarbanes oxley periods". The accounting review.

Cohen, D.A. \& P. Zarowin. (2010). "Accrual Based and Real Earning Management Activities Around Seasoned Equity Offering". Journal of Accounting and Economics 50, 2-19.

Dickinson, Victoria, 2007. "Cash Flow Patterns as a Proxy for Firm Life Cycle”. Working paper Fisher School of Accounting, Warrington College of Business University of Florida.

Graham , J R.Harvey,CR dan Rajgopal, S.2005.The economic implication of corporate financial reporting. Journal of accounting and economics. Vol.40.

Govindarajan 2005. Management Control System. Edisi Pertama. Penerbit Salemba Empat. Jakarta.

Hastuti, Sri. 2006. "Perbedaan Perilaku Earnings Management Berdasarkan pada Life Cycle Perusahaan". Tesis, Universitas Gadjah Mada, Yogyakarta.

Hastuti, Sri. 2011. "Studi tentang Pemilihan Kebijakan Akuntansi dan Hubungannya dengan Manajemen Laba: Analisis dengan Pendekatan Siklus Hidup Perusahaan dan Ukuran Perusahaan”. DIPA Kopertis Wilayah V, Yogyakarta. 
Hastuti Theresia dan Ghozali Imam. 2015. "Polish journal of management studies the effect of company life cycle on the accrual earning management with internal control system as moderating variabel". Polish journal of management studies.

Lukita, Carolyn. 2016. "Perbedaan perilaku manajemen laba berdasarkan siklus hidup perusahaan". Skripsi, Universitas Bengkulu, Bengkulu.

Pachariyanok dan Parapok. 2015."The relationship between company life cycle and the choice of earning management". Thesis.

Restuti , Mitha. 2015. "Perbedaan earning management berdasarkan pada tahapan life cycle perusahaan yang terdaftar di Bursa Efek Indonesia". Jurnal Ekonomi dan Bisnis Vol 18.

Roychowdhury,Sugata. 2006. "Earnings Though Real Activitie Manipulation". Journal of Accounting and Economics Vol. 42 No. 3: 335- 370.

Scott, William R. 2000. Financial Accounting Theory. Second Edition, Prentice Hall Inc.

Sulistyanto , Sri. 2008. Manajemen Laba:Teori dan Model Empiris. Jakarta: Grasindo 